\title{
PENGARUH MODEL PEMBELAJARAN CONCEPTUAL UNDERSTANDING PROCEDURES (CUPS) TERHADAP HASIL BELAJAR FISIKA SISWA KELAS XI SMA NEGERI 5 MATARAM TAHUN AJARAN 2015/2016
}

\author{
Mei Lina Wulandari, Sutrio, Satutik Rahayu \\ Program Studi Pendidikan Fisika \\ FKIP, Universitas Mataram \\ Jalan Majapahit No. 62, Mataram \\ E-mail: mei.lina.wulandari19@gmail.com
}

\begin{abstract}
This study aimed to determine the effect of Conceptual Understanding Procedures (CUPs) learning model on physics learning outcomes of student class XI SMAN 5 Mataram academic year 2015/2016. Conceptual Understanding Procedures (CUPS) is a learning model that consists of three phases namely learning phase of individual work, group work phase, and the phase of presentation of the group's work. The results of a study which examined learning outcomes on cognitive aspects of the C1 to C6 (knowledge, comprehension, application, analysis, synthesis and evaluation). Type of research is a quasi-experimental research with posttest-only control group design. The sample was chosen by cluster random sampling. Data of learning outcomes were analyzed using t-test. Results showed that there was an effect of Conceptual Understanding Procedures (CUPs) learning model on students' physics learning outcomes in Class XI SMAN 5 Mataram academic year 2015/2016.
\end{abstract}

Keywords: CUPs, learning outcomes.

\section{PENDAHULUAN}

Ilmu Pengetahuan Alam (IPA) merupakan disiplin ilmu yang terkait dengan pengetahuan alam secara luas (Muammar et. al., 2015). Pengetahuan tersebut diperoleh melalui pembelajaran, penguasaan pengetahuan, proses penemuan, konsepkonsep, dan fakta-fakta yang melingkupi kebenaran dari hukum-hukum alam yang terjadi. Sebagai cabang ilmu pengetahuan alam, fisika mempelajari segala sesuatu yang berhubungan dengan gejala-gejala alam. Fisika mempelajari tentang bagaimana suatu gejala atau fenomena alam dapat terjadi. Hakikat fisika yang paling menonjol yakni kumpulan pengetahuan berupa fakta, teori, rumus, maupun hukum. Semua produk tersebut diperoleh melalui proses berfikir dan berbagai macam kegiatan ilmiah. Bermula dari adanya rasa ingin tahu yang besar mengantarkan para ilmuan menghasilkan suatu kumpulan pengetahuan yang disusun secara sistematis yang kemudian saat ini diajarkan kembali dalam pembelajaran fisika.
Pembelajaran fisika di sekolah sudah diajarkan sejak dari sekolah dasar. Pada tingkatan sekolah dasar, materi pembelajaran fisika yang diajarkan hanya berupa fakta sederhana mengenai suatu gejala alam. Kemudian, barulah pada tingkat sekolah menengah materi pembelajaran fisika yang diajarkan mulai berkembang menjadi lebih luas dan kompleks. Adapun tujuan pembelajaran fisika yang tertuang dalam kurikulum 2013 ialah mendorong siswa untuk menemukan dan mentransformasikan informasi kompleks, mengecek informasi baru dengan aturan-aturan lama di dalam pikirannya, dan merevisinya apabila aturan-aturan itu tidak lagi sesuai (Listiawati et. al., 2015).

Pembelajaran fisika di sekolah sudah diajarkan sejak dari sekolah dasar. Pada tingkatan sekolah dasar, materi pembelajaran fisika yang diajarkan hanya berupa fakta sederhana mengenai suatu gejala alam. Kemudian, barulah pada tingkat sekolah menengah materi pembelajaran fisika yang diajarkan mulai berkembang menjadi lebih luas 
dan kompleks. Pembelajaran fisika yang sering dijumpai di sekolah ialah pembelajaran fisika dengan menggunakan metode ceramah. Pada metode pembelajaran tersebut siswa tidak didorong untuk aktif dalam menemukan informasi. Siswa cenderung belajar secara pasif dan hanya memahami fisika sebatas definisi saja sehingga tidak sampai pada konsep sebenarnya.

Berdasarkan permasalahan diatas, maka diperlukan model pembelajaran yang mampu melibatkan siswa secara aktif sehingga pembelajaran menjadi lebih bermakna. Suparno dalam Yamin menjelaskan bahwa pembelajaran bermakna merupakan suatu proses pembelajaran dimana informasi baru dihubungkan dengan informasi yang telah dimiliki oleh seseorang yang sedang dalam proses pembelajaran (Yamin, 2013). Proses pembelajaran tersebut tidak hanya menghafal konsep-konsep atau fakta-fakta belaka, tetapi juga menghubungkan konsep-konsep untuk menghasilkan pemahaman secara utuh sehingga konsep yang dipelajari tidak mudah dilupakan dan hasil belajar yang diperoleh menjadi lebih maksimal.

Proses pembelajaran melibatkan tiga komponen pokok yakni penyampai pesan (guru), penerima pesan (murid) dan pesan yang berupa materi pembelajaran (Hikmawati, 2015). Dalam pembelajaran terjadi interaksi antara guru sebagai penyampai pesan berupa materi pembelajaran dan murid sebagai penerimanya. Proses pembelajaran berlangsung melalui berbagai macam model. Model pembelajaran fisika dimanfaatkan sebagai pedoman dalam merancang kegiatan yang dapat membantu siswa memperoleh pengetahuan baru maupun mengembangkan pengetahuan yang sudah ada sebagai dasar berkembangnya ilmu dan teknologi. Model pembelajaran fisika yang diajarkan pada penelitian ini ialah model pembelajaran Conceptual Understanding Procedures (CUPs).
CUPs merupakan suatu model pembelajaran yang bertujuan untuk membantu meningkatkan meningkatkan hasil belajar siswa. Pengetahuan yang dimiliki siswa dengan belajar berdasarkan pemahaman konsep secara menyeluruh dan bukan hanya sekedar hafalan akan lebih bertahan lama di ingatan dan dapat mengoptimalkan hasil belajar (Anggreni et. al., 2013). Model pembelajaran CUPs merupakan model pembelajaran yang berlandaskan kepada pendekatan kontruktivisme yang didasari pada kepercayaan bahwa siswa mengkontruksi pemahaman konsep dengan memperluas atau memodifikasi pengetahuan yang sudah ada (Hikmah et. al., 2015).

Dalam suatu kelas konstruktivis, pengajar melihat siswa sebagai peserta yang aktif dalam proses pembelajaran sewaktu mereka mencari makna dengan cara mengaitkan pengetahuan lama dengan pengetahuan baru yang mereka miliki. Pada model pembelajaran Conceptual Understanding Procedures (CUPs) siswa dibagi ke dalam kelompok kecil yang dibentuk secara heterogen dengan mempertimbangkan kemampuan siswa dan diberikan bahan untuk diskusi (Hikmah et. al., 2015). Guru lebih berperan sebagai fasilitator, membantu mengaktifkan siswa dalam pembentukan pengetahuan, sehingga siswa tidak hanya duduk, memperhelajatikan, dan menerima apa yang disampaikan oleh guru, tetapi siswa lebih aktif membentuk pengetahuan. Selain itu siswa juga didorong untuk bertukar pikiran dengan temannya dalam mengkomunikasikan gagasangagasan yang mereka miliki.

Tiga fase pembelajaran CUPs yakni fase kerja individu, fase kerja kelompok, dan fase presentasi hasil atau diskusi kelas. Fase pertama diawali dengan penyampaian materi pembelajaran dan demonstrasi sederhana yang ditampilkan oleh guru. Kemudian siswa mengerjakan lembar kerja individu yang diberikan oleh guru. Fase kedua yakni fase kerja kelompok. Pada fase ini siswa dibentuk menjadi 
beberapa kelompok kecil heterogen. Siswa diminta untuk bekerja secara berkelompok dalam kegiatan eksperimen atau diskusi kelompok. Fase terakhir ialah fase diskusi kelas. Setiap perwakilan dari kelompok diminta untuk mempresentasikan hasil diskusi kelompoknya di depan kelas. Pada fase ini peran guru sebagai fasilitator sangat diperlukan agar proses diskusi kelas dapat berjalan baik dan mampu menghasilkan suatu kesimpulan yang sesuai dengan konsep yang sebenarnya.

Model Pembelajaran CUPs merupakan pembelajaran yang diperkuat oleh peran aktif siswa dalam belajar atau bersifat student center (Anggreni et. al., 2013). Pada model pembelajaran CUPs guru lebih berperan sebagai fasilitator dalam mengaktifkan dan membentuk pengetahuan sehingga siswa tidak hanya duduk dan menerima apa yang disampaikan guru, tetapi siswa lebih aktif dalam membangun pemahaman yang berkaitan dengan materi pembelajaran (Hikmah et. al., 2015).

Adapun hasil belajar adalah perubahan kemampuan yang diperoleh setelah adanya pelaksanaan kegiatan pembelajaran (Gunada et. al., 2015). Perubahan kemampuan yang diperoleh ditandai dengan adanya perubahan tingkah laku. Perubahan kemampuan sebagai hasil belajar dapat berupa perubahan kemampuan berpikir kognitif, perubahan dalam aspek afektif dan emosional.

Hasil belajar yang diteliti merupakan hasil belajar dalam aspek kognitif. Aspek kognitif merefleksikan konsep-konsep keilmuan yang harus dikuasai oleh siswa melalui proses belajar mengajar. Dalam aspek kognitif terdapat enam jenjang proses berpikir, yakni kemampuan mengingat, memahami, menerapkan, menganalisis, mensintesis dan mengevaluasi (Jiniarti et. al., 2015). Dimana hasil belajar tersebut digunakan untuk melihat pengaruh dari model pembelajaran yang digunakan.

Salah satu model pembelajaran yang dianggap mampu menjadi solusi permasalahan tersebut ialah model pembelajaran Conceptual Understanding Procedures (CUPs). Model pembelajaran CUPs merupakan model pembelajaran yang didasari atas kepercayaan bahwa siswa mampu membentuk suatu pengetahuan baru berdasarkan pengalaman yang sudah mereka miliki. Berdasarkan uraian tersebut, peneliti tertarik untuk melakukan penelitian pengaruh Model Pembelajaran Conceptual Understanding Procedures (CUPs) terhadap hasil belajar fisika siswa di sekolah.

\section{METODE PENELITIAN}

Jenis penelitian yang digunakan yakni penelitian quasi experiment (eksperimen semu). Pada penelitian quasi eksperiment, kelompok kontrol yang dimiliki tidak dapat sepenuhnya berfungsi untuk mengontrol variabel-variabel luar yang mempengaruhi pelaksanaan eksperimen (Sugiyono, 2013). Desain penelitian yang digunakan dalam penelitian ini ialah Posttest-Only Control Group Design. Pada desain penelitian tersebut terdapat dua kelompok yang dipilih secara random.

Adapun variabel dalam penelitian terdiri dari variabel bebas, variabel terikat dan variabel kontrol. Variabel bebas merupakan variabel yang mempengaruhi sebab terjadinya perubahan atau timbulnya variabel terikat. Variabel bebas dalam penelitian ini yakni model pembelajaran Conceptual Understanding Procedures (CUPs) pada kelompok eksperimen dan model pembelajaran direct instruction pada kelompok kontrol. Variabel terikat merupakan variabel akibat karena adanya variabel bebas (Sugiyono, 2013). Variabel terikat pada penelitian ini ialah hasil belajar fisika siswa pada ranah kognitif. Variabel kontrol di dalam penelitian ini berupa materi, tujuan pembelajaran dan instrumen yang digunakan.

Penelitian ini dilaksanakan mulai bulan Oktober 2015 sampai dengan Mei 2016. Tempat pelaksanaan penelitian di SMA Negeri 5 Mataram. Populasi dalam penelitian ini ialah 
seluruh siswa kelas XI MIA SMA Negeri 5 Mataram tahun pelajaran 2015/2016 yang berjumlah 278 siswa dan terbagi dalam 7 kelas. Pemilihan populasi penelitian di sekolah tersebut dikarenakan proses pembelajaran fisika di kelas XI MIA mewakili rata-rata pelaksanaan pembelajaran fisika di SMA. Adapun yang menjadi sampel penelitian yakni siswa kelas XI MIA 3 sebagai kelas ekperimen sebanyak 39 orang dan kelas XI MIA 4 sebagai kelas kontrol sebanyak 40 orang.

Instrumen penelitian merupakan alat yang digunakan untuk mengukur variabel penelitian (Sugiyono, 2013). Instrumen yang digunakan pada penelitian yakni berupa tes pilihan ganda sebanyak 20 soal untuk mengukur kemampuan kognitif siswa. Sebelum tes pilihan ganda digunakan, terlebih dahulu dilakukan uji validitas. Uji validitas dilakukan dengan menggunakan rumus korelasi product moment dengan angka kasar. Kemudian reliabilitas soal dilihat dari nilai koefisien reabilitas yang dapat diperoleh dengan rumus Kuder dan Richardson (K-R 20). Analisis tingkat kesukaran soal dilakukan dengan menggunakan indeks kesukaran. Rumus untuk menentukan daya pembeda (DP) yakni selisih proporsi jawaban benar antara dua kelompok siswa.

Teknik pengumpulan data yang digunakan ialah dengan menggunakan tes untuk mengetahui pengaruh perlakuan terhadap hasil belajar siswa. Tes diberikan kepada kelompok eksperimen dan kelompok kontrol setelah kedua kelompok tersebut diberikan perlakuan. Tes yang digunakan adalah tes pilihan ganda yang berjumlah 20 soal. Uji homogenitas dilakukan untuk memperoleh asumsi bahwa sampel penelitian diawali dari kondisi yang sama. Sedangkan uji normalitas bertujuan untuk mengetahui apakah data tes sudah terdistribusi secara normal. Uji hipotesis dilakukan untuk mengetahui perbedaan hasil belajar antara kelompok eksperimen yang dengan kelompok kontrol dengan analisis data hasil tes menggunakan uji-t.

\section{HASIL DAN PEMBAHASAN}

Berdasarkan hasil posttest siswa diperoleh nilai rata-rata hasil belajar kelas eksperimen sebesar 85 dan kelas kontrol sebesar 77. Hasil posttest diperoleh berdasarkan tes pilihan ganda sebanyak 20 soal yang diberikan setelah kelas eksperimen dan kelas kontrol diajarkan dengan model pembelajaran yang berbeda. Nilai tertinggi pada kelas eksperiment 100 dan kelas kontrol 90, sedangkan nilai terendah pada kelas eksperimen yaitu 70 dan kelas kontrol 60 . Perbedaan nilai tes hasil belajar fisika siswa pada kedua sampel digambarkan pada Gambar 1 berikut:

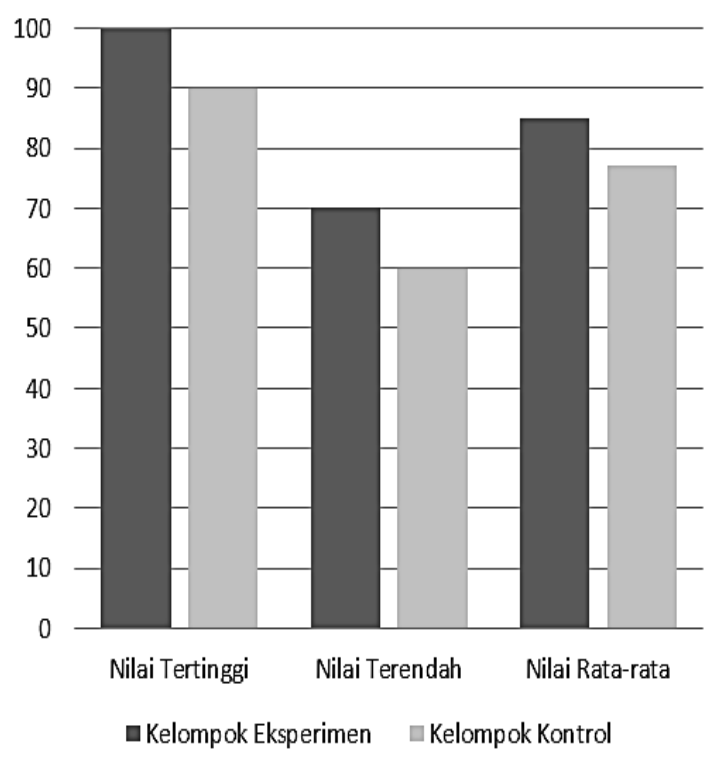

Gambar 1. Perbedaan nilai tes hasil belajar fisika siswa

Selanjutnya dilakukan uji homogenitas menggunakan persamaan uji-F dengan taraf signifikasi $5 \%$. Berdasarkan hasil perhitungan diperoleh $F_{\text {hitung }}$ sebesar 1,26 dengan $F_{\text {tabel }}$ sebesar 1,75. Karena nilai $F_{\text {hitung }}<F_{\text {tabel, }}$, maka kedua sampel dapat dikatakan homogen.

Data posttest yang diperoleh selanjutnya dilakukan uji normalitas. Perhitungan pada taraf signifikasi $5 \%$ menghasilkan $x_{\text {hitung }}^{2}$ sebesar 
4,96 pada kelas eksperimen dan $x_{\text {hitung }}^{2}$ sebesar 1,61 pada kelas kontrol, dengan derajat kebebasan sebesar 4 sehingga diperoleh nilai $x_{\text {tabel }}^{2}$ sebesar 9,48. Nilai $x_{\text {hitung yang lebih }}^{2}$ kecil daripada $x_{\text {tabel }}^{2}$ menunjukkan bahwa hasil belajar kedua kelas sampel terdistribusi secara normal. Untuk lebih jelasnya, data hasil posttest hasil belajar siswa dapat dilihat pada Tabel 1.

Tabel 1. Data posttest hasil belajar siswa

\begin{tabular}{|c|c|c|}
\hline \multirow[b]{2}{*}{ Komponen } & \multicolumn{2}{|c|}{ Data Posttest } \\
\hline & $\begin{array}{c}\text { Kelas } \\
\text { Eksperimen }\end{array}$ & $\begin{array}{c}\text { Kelas } \\
\text { Kontrol }\end{array}$ \\
\hline Jumlah Siswa & 36,0 & 37,0 \\
\hline Nilai Tertinggi & 100,0 & 90,0 \\
\hline Nilai Terendah & 70,0 & 60,0 \\
\hline Rata-rata & 85,0 & 77,0 \\
\hline Standar Deviasi & 5,8 & 5,2 \\
\hline Uji Homogenitas & \multicolumn{2}{|c|}{ Homogen } \\
\hline Uji Normalitas & Normal & Normal \\
\hline
\end{tabular}

Dari data postest hasil belajar siswa dapat diketahui bahwa data dalam penelitian terdistribusi normal, sehingga uji hipostesis dapat dilaksanakan. Uji hipotesis yang digunakan ialah uji- $t$ dua pihak. Berdasarkan kriteria pengujian uji- $t$ dua pihak, jika harga

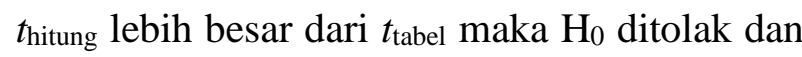
$\mathrm{H}_{\mathrm{a}}$ diterima.

Hasil uji distribusi data menjelaskan bahwa sebaran data dikedua kelas adalah normal dan homogen artinya bahwa dalam melakukan uji hipotesis digunakan uji-t dengan persamaan polled varians $\left(n_{1} \neq n_{2}\right)$. Dari hasil perhitungan diperoleh nilai $\mathrm{t}_{\text {hitung }}=6,96 \mathrm{dan} \mathrm{t}_{\text {tabel }}$ $=1,99$ pada taraf signifikan $5 \%$ dengan $d b=71$.

Berdasarkan kriteria pengambilan keputusan menunjukkan bahwa $t_{\text {tabel }}<t_{\text {hitung, }}$ sehingga Ha diterima dan $\mathrm{H}_{0}$ ditolak. Ha diterima menunjukkan bahwa ada pengaruh model pembelajaran Conceptual Understanding Procedures (CUPs) terhadap hasil belajar fisika siswa.

Berdasarkan hasil analisis data postest, diperoleh bahwa nilai rata-rata hasil belajar fisika kelas eksperimen lebih tinggi dibandingkan kelas kontrol. Hal ini menunjukkan bahwa siswa kelas eksperimen yang diajarkan dengan menggunakan model pembelajaran CUPs lebih baik dalam menjawab dan menyelesaikan soal-soal yang diberikan. Dimana soal yang diberikan berupa 20 soal pilihan ganda dengan aspek kognitif C1 sampai dengan C6 (pengetahuan, pemahaman, penerapan, analisis, sintesis dan evaluasi).

Adanya pengaruh model pembelajaran CUPs terhadap hasil belajar siswa dikarenakan model tersebut membantu siswa mengembangkan pemahaman terkait konsep yang sedang dipelajari. Novak menyatakan bahwa pengorganisasian proses pembelajaran sangat penting dalam membangun pemahaman terhadap suatu konsep pada siswa. Proses pembelajaran yang baik tidak hanya memperhatikan penyampaian konsep, tetapi juga memperhatikan proses dalam penyampaian konsep dan proses pemahaman konsep oleh siswa (Cakir, 2008).

Dalam aplikasinya model pembelajaran CUPs membantu proses pemahaman konsep siswa melalui latihan yang dilakukan secara individu dan kemudian secara kelompok. Adanya fase kerja secara berkelompok dan diskusi kelas adalah untuk merangsang pemikiran aktif pada siswa. Siswa menjelaskan gagasannya dan membandingkannya dengan gagasan yang dimiliki siswa lain. Hal ini menyebabkan timbulnya kesadaran atas gagasan yang salah dan siswa memperoleh pemahaman yang benar dari hasil diskusi (McKittrick et. al., 1999).

Pembelajaran CUPs yang diterapkan pada kelas eksperimen membantu siswa dalam membangun pemahaman selama kegiatan pembelajaran berlangsung. Selama proses pembelajaran berlangsung, siswa dituntut berperan aktif mencari informasi dan berdiskusi. Menurut Subarkah et. al., (2014) model pembelajaran CUPs dalam penerapannya 
memberikan perlakuan dan peranan yang berbeda berdasarkan kemampuan akademik yang dimiliki siswa pada setiap kelompok. Siswa yang memiliki kemampuan lebih tinggi membantu teman dalam kelompok untuk mencari informasi dan mendiskusikannya serta memberikan arahan terkait pembuatan hasil diskusi.

Dalam pembelajaran CUPs terdapat tiga fase pembelajaran yang dilaksanakan oleh siswa pada kelas eksperimen. Tiga fase pembelajaran CUPs yakni fase kerja individu, fase kerja kelompok, dan diskusi kelas (Ismawati et. al., 2014). Pada fase kerja individu siswa mengerjakan lembar kerja secara perseorangan. Lembar kerja yang diberikan berupa persoalan mengenai fenomena yang berkaitan dengan teori gas ideal di lingkungan sekitar. Dengan meminta siswa memberikan jawaban sesuai dengan pemahamannya sendiri, siswa terdorong untuk berfikir secara aktif dalam menyelesaikan persoalan. Pemahaman dan jawaban yang berbeda di awal fase pembelajaran akan meningkatkan rasa ingin tahu siswa terhadap teori yang dipelajari.

Kemudian, siswa dikelompokkan dalam beberapa kelompok heterogen. Dalam fase kerja kelompok, siswa diberikan lembar kerja berdasarkan ekspermen sederhana atau simulasi yang berkaitan dengan persoalan dalam lembar kerja individu. Adanya perbedaan pemahaman awal antara siswa dalam satu kelompok menimbulkan terjadinya diskusi dalam kelompok. Siswa cenderung menjadi lebih aktif karena memiliki peran dan pemahamannya masing-masing dalam kelompok. Selain itu, menurut Hikmah et. al., (2015) siswa juga didorong untuk mengemukakan argumentasi dan bertukar pikiran. Dengan diskusi yang terjadi dalam kelompok, siswa mencoba menemukan satu pemahaman konsep yang tepat.

Pada fase akhir yakni fase diskusi kelas, guru sebagai fasilitator meminta beberapa kelompok menyampaikan hasil diskusi di depan kelas. Siswa diberi kesempatan untuk menanggapi dan membandingkan hasil diskusi masing-masing dengan kelompok lainnya. Adanya perbedaan hasil diskusi antar kelompok menimbulkan terjadinya diskusi kelas. Anggreni et. al., (2013) menyatakan bahwa pada kegiatan inilah siswa mulai mempertahankan jawabannya dan memberi pertanggungjawaban atas apa yang telah ditulisnya dalam lembar kerja. Siswa dalam diskusi kelas berusaha menemukan satu pemahaman yang sama yang dianggap paling tepat. Guru sebagai fasilitator membimbing dalam menyimpulkan pemahaman siswa yang berbeda-beda sehingga diperoleh konsep yang tepat. Guru juga berperan dalam mengelola kelas sehingga proses diskusi berjalan dengan baik.

Pada pelaksanaan penelitian, demonstrasi diberikan di awal pembelajaran untuk meningkatkan rasa ingin tahu dan memberi motivasi pada siswa untuk menjawab pertanyaan pada lembar individu. Demonstrasi yang menarik dilakukan untuk meningkatkan minat siswa dalam proses pembelajaran. Minat siswa yang tinggi di awal pembelajaran akan mendorong siswa untuk mengkontruksi pemahamannya secara mandiri. Menurut Ismawati et. el., (2014) dalam mengkontruksi dan menjawab pertanyaan lembar individu akan muncul sikap keraguan pada diri siswa. Sikap inilah yang mendorong siswa untuk lebih aktif dalam kegiatan kerja kelompok. Siswa yang masih ragu terhadap hasil pemikirannya akan berusaha mengkonfirmasi dan membandingkan jawaban yang dimiliki dengan teman satu kelompok atau bertanya pada guru. Keadaan tersebut menjadikan kegiatan diskusi dalam kelompok menjadi lebih komunikatif.

Selain dilakukan demonstrasi pada awal pembelajaran, pada pelaksanaan penelitian juga dilakukan kegiatan eksperimen, Kegiatan eksperimen dilakukan di tengah kerja 
kelompok. Setelah kelompok diberikan lembar kerja yang harus dikerjakan, kelompok diberikan kesempatan untuk melaksanakan kegiatan eksperimen yang telah ditentukan. Menurut Firmansyah et. al., dengan kegiatan eksperimen siswa tidak hanya mendengarkan, mencatat, dan menghafal materi yang disampaikan oleh guru, tetapi siswa diharapkan mampu berfikir, mencari, mengolah data dan berkomunikasi dalam proses pembelajaran. Melalui kegiatan eksperimen pada pembelajaran CUPs siswa diberi kesempatan untuk menjawab pertanyaan dan mengkontruksi kembali pemahamannya. Melalui eksplorasi pada kegiatan eksperimen siswa juga dapat menemukan pengetahuan baru yang dapat digunakan untuk menemukan solusi atas persoalan sains yang ada.

Pembelajaran Conceptual Understanding Procedures memberi kesempatan pada siswa untuk membandingkan pemahamannya dengan pemahaman siswa lainnya. Dengan membandingkan dan menilai secara bersamasama akan meningkatkan kemampuan berpikir dan peran aktif siswa dalam proses pembelajaran. Pembelajaran yang melibatkan peran aktif siswa dalam prosesnya akan lebih menarik minat belajar siswa. Siswa akan menjadi lebih percaya diri dan tertarik untuk melaksanakan pembelajaran pada pertemuan selanjutnya. Hal tersebut sesuai dengan pernyataan Hikmah et. al., (2015) dalam penelitiannya yang menyatakan bahwa adanya pengalaman belajar dalam menemukan konsep sendiri tentunya berdampak lebih baik pada siswa baik dari sisi keaktifan, kemandirian, tanggung jawab maupun kerjasama, sehingga siswa bisa dioptimalkan potensinya dalam pembelajaran. Sehingga siswa betul-betul mampu menjadi fokus atau pusat dalam pembelajaran.

Dalam penelitiannya Mills et. al., (1999) menyatakan bahwa siswa memberikan respon positif setelah mendapatkan pembelajaran
CUPs. Respon positif tersebut yaitu, siswa sangat antusias terhadap kegiatan pembelajaran CUPs. Sikap antusias tersebut dapat meningkatkan minat belajar fisika siswa di dalam kelas. Siswa juga sangat menikmati setiap kegiatan dalam proses pembelajaran. Siswa memanfaatkan kegiatan diskusi untuk memodifikasi pengetahuan yang mereka miliki. Siswa sadar bahwa pemahaman yang tepat pada suatu konsep sangatlah penting. Siswa memiliki kesadaran untuk memperbaiki cara mereka dalam mempelajari sains. Belajar tidak lagi hanya mendengarkan penjelasan yang disampaikan oleh guru, melainkan dapat berupa eksplorasi dalam kegiatan eksperimen dan diskusi bersama-sama mengenai suatu konsep guna meningkatkan pengetahuan yang mereka miliki.

Hasil penelitian Ismawati et. al., (2014) menunjukkan adanya peningkatan curiosity (rasa ingin tahu) dan pemahaman konsep pada siswa dengan pokok bahasan pemuaian zat. Peningkatan curiosity pada siswa memiliki hubungan positif dengan peningkatan pemahaman konsep. Siswa yang memiliki curiosity tinggi memiliki keinginan belajar yang lebih tinggi. Hal tersebut dapat meningkatkan pemahaman siswa terhadap suatu konsep materi, dengan peningkatan pemahaman konsep pada siswa eksperimen sebesar 0,67 yang termasuk dalam kategori sedang. Pemahaman konsep diperoleh dengan mengkontruksi pemahaman awal yang dimiliki oleh siswa. Dengan membangun pemahaman mereka sendiri, siswa menjadi lebih berperan aktif sehingga pembelajaran menjadi terpusat pada siswa.

Peran siswa sebagai pusat pembelajaran akan meningkatkan kemampuan berpikir siswa, sehingga pengetahuan yang dimiliki bertahan lama dan dapat digunakan dalam menyelesaikan suatu persoalan. Dimana, kemampuan menyelesaikan persoalan dengan baik akan mengoptimalkan hasil belajar yang diperoleh. 
Oleh karna itu siswa yang diajarkan dengan model pembelajaran CUPs memiliki hasil belajar yang lebih baik. Sehingga model pembelajaran CUPs terbukti mampu meningkatkan hasil belajar fisika siswa di sekolah.

\section{PENUTUP}

Berdasarkan hasil penelitian dan pembahasan, maka dapat disimpulkan bahwa terdapat pengaruh model pembelajaran Conceptual Understanding Procedures (CUPs) terhadap hasil belajar fisika siswa kelas XI SMA Negeri 5 Mataram tahun ajaran 2015/2016. Adapun saran yang dapat diberikan yaitu diharapkan dengan adanya model pembelajaran Conceptual Understanding Procedures (CUPs) menjadi salah satu model pembelajaran alternatif yang dapat diterapkan di sekolah dalam upaya meningkatkan hasil belajar fisika siswa.

\section{REFERENSI}

Anggreni, Kd. R., Meter, I Gd., \& Wiarta, I Wyn. 2013. Model Pembelajaran Conceptual Understanding Procedures Berpengaruh Terhadap Hasil Belajar Matematika Siswa Kelas V SD Gugus VII Kompiang Sujana Denpasar Barat. Jurnal Universitas Pendidikan Ganesha. 1(1), 12-21.

Cakir, M. 2008. Constructivist Approaches to Learning in Science Their Implication for Science Pedagogy: A Literature Review. International Journal of Environmental \& ScienceEducation, 3(4), 193-206.

Firmansyaah A., Kosim, \& Ayub, S. 2015. Pengaruh Model Pembelajaran Berbasis Masalah Dengan Metode Eksperimen Pada Materi Cahaya Terhadap Hasil Belajar Fisika Siswa Kelas VIII SMPN 2 Gunungsari Tahun Ajaran 20142015.
Jurnal Pendidikan Fisika dan Teknologi. 1(3), 154-160.

Gunada, I W., Sahidu, H., \& Sutrio. 2015. Pengembangan Perangkat Pembelajaran Fisika Berbasis Masalah untuk Meningkatkan Hasil Belajar dan Sikap Ilmiah Mahasiswa. Jurnal Pendidikan Fisika dan Teknologi. 1(1), 38-46.

Hikmah, N., Baidowi, \& Kurniati, N. 2015. Penerapan Model Pembelajaran Conceptual Understanding Procedures (CUPs) untuk Meningkatkan Aktivitas dan Hasil Belajar Matematika Siswa Kelas X SMA Negeri 7 Mataram. Jurnal Pijar MIPA. 9(2), 84-88.

Hikmawati. 2015. Pembelajaran Fisika dengan Model Siklus Belajar 5-E (Engage, Explore, Explain, Elaborate, Evaluate) Sebagai Upaya Meningkatkan

Kecakapan Hidup Siswa. Jurnal Pendidikan Fisika dan Teknologi. 1(1), 24-37.

Ismawati, Nugroho S. E., \& Dwijananti P. 2014. Penerapan Model Pembelajaran Conceptual Understanding Procedures Untuk Meningkatkan Curiosty Dan Pemahaman Konsep Siswa. Jurnal Pendidikan Fisika Indonesia. 10(1), 2227.

Listiawati, W., Gunawan \& Sutrio. 2015. Pengaruh Penerapan Model Pembelajaran Berbasis Masalah Berbantuan Simulasi Interaktif terhadap Hasil Belajar Fisika Siswa Kelas VIII SMPN 1 Pujut Tahun Pelajaran 2013/2014. Jurnal Pendidikan Fisika dan Teknologi. 1(1), 82-86.

McKittrick, B., Mulhall, P., \& Gunstone,R. 1999. Improving Understanding in Physics: An Effective Teaching Procedure. Australian Science Teachers Journal. 45(3), 27-33. 
Mills, D., McKittrick, B., Mulhall, P., \& Feteris, S. 1999. CUP: Cooperative Learning That Works. Physics Education, 34(1), 11-16.

Muammar, H., Harjono, A., \& Gunawan. 2015. Pengaruh Model Pembelajaran Assure dan Pengetahuan Awal Terhadap Hasil Belajar IPA-Fisika Siswa Kelas VIII SMPN 22 Mataram. Jurnal Pendidikan Fisika dan Teknologi. 1(3), 166-172.

Subarkah, B., Nurbaity, \& Darsef. 2014. Pengaruh Model Pembelajaran Kooperatif Conceptual Understanding Procedures (CUPS) Terhadap Hasil Belajar Kimia. Jurnal Riset Pendidikan Kimia. 4(1), 245-250.

Sugiyono. 2013. Statistika untuk Pendidikan. Bandung: Alfabeta.

Yamin, M. 2013. Paradigma Baru Pembelajaran. Jakarta: Refrensi. 